Ora, muitos juristas do Terceiro Mundo levantam-se contra essa tese da internacionalização dos contratos, pois alegam que essa internacionalização dá margem a que empresas multinacionais tenham uma certa preponderância na negociação contra pequenos Estados ou mesmo contra pequenas empresas do governo de determinado país. O prof. Marcelo Hulkes, da Faculdade de Direito da Universidade de São Paulo, em tese recente, levantou-se contra essa posição dizendo que a internacionalização do contrato estaria contra os países em desenvolvimento. Eu não penso assim; não penso porque os países em desenvolvimento, eé por isso que nós estamos aqui, também estão contratando no exterior, e muito, e também com países do mesmo ranking, em desenvolvimento, ou até menos desenvolvidos do que nós.

Acreditamos que a aplicação apenas da lei do país com que o Brasil vai negociar, por exemplo, na África, pode não ser a melhor forma. Portanto, a arbitragem internacional e até mesmo os princípios gerais do direito internacional podem interessar ao Brasil. Essa questão merece ser examinada com cuidado, é uma questão de política do direito ou do direito por fazer sobre a qual convido à reflexão.

\title{
Domínio da lei, nascimento, extinção e inexecução das obrigações no contrato internacional
}

\author{
Frederico José Straube, chefe do \\ Departamento Jurídico da Hidroservise, \\ Engenharia de Projetos Ltda.
}

Frederico José Straube
O princípio da competência geral da lei do contrato terá abrangência maior ou menor, dependendo do que se entenda exatamente pela expressão "efeitos do contrato". Sem determinação da noção de efeitos do contrato, não tem maiores repercussões, no plano interno. A precisão torna-se essencial no plano internacional, na medida em que sua análise pode conduzir a conseqüências jurídicas diferentes. Caso a expressão "efeitos do contrato" seja tomada em um sentido tão amplo, de modo a que ela compreenda todos os atos que estejam ligados à operação contratual, desde a criação do liame obrigacional até o desaparecimento total da situação contratual, parece duvidoso que a competência da lei do contrato seja geral. O princípio da competência da lei do contrato não sofre maiores contestações no que concerne à criação mesmo do liame obrigacional, ou seja, no que diz respeito à força obrigatória do contrato. É, porém, no que tange à execução do contrato que as objeções feitas à competência da lei contratual têm sido mais vivas. Os argumentos que embasam tais objeções não têm senão valor limitado, visto que a unidade da operação contratual determina, em longa medida, a aplicação da lei segundo a qual a validade do contrato foi apreciada, ou seja, a lei do contrato. A solução parece se impor, também, ainda que sob certas reservas, quando se trata de determinar as conseqüências da inexecução do contrato que são ligadas ao princípio da força obrigatória do contrato. No exame da delimitação do domínio da lei do contrato enfocaremos o assunto sob três aspectos diferentes, conforme já havia salientado, embora sejam eles correlatos: o primeiro concerne às obrigações das partes; o segundo diz respeito à execução do contrato; o terceiro se refere às conseqüências da inexecução do contrato.

A lei do contrato determina, em princípio, a extenção das obrigações criadas pelo contrato a cargo de uma e de outra parte ou das duas, quando o contrato é sinalagmático. Este princípio, em grande medida, deverá permitir igualmente fixar a duração dessas obrigações.

Dois pontos devem ser enfocados quando se trata da extensão das obrigações: de um lado a determinação das obrigações nascidas do contrato e, de outro lado, a modificação destas em função de circunstâncias posteriores à conclusão do contrato. A determinação das obrigações nascidas do contrato e de seu conteúdo, demandam alguns comentários, pois é evidente que a insuficiência de estipulação das partes acarreta a necessidade de suplementação, fundadas em disposições de um sistema legal positivo. Da mesma forma que a lei aplicável ao 
contrato delimitou, no estágio de formação do contrato, imperativamente o conteúdo legal da convenção, igualmente as disposições supletivas dessa lei complementarão as previsões das partes. A observação é, de resto, igualmente válida no que concerne às obrigações imperativamente impostas, ainda que certas atenuações devam ser carreadas a esses princípios, por força do caráter de leis de polícia de certas disposições.

Mais delicados, entretanto, são os problemas sugeridos pela interpretação do contrato. Com efeito, enquanto a vontade das partes na determinação do conteúdo do contrato não está claramente expressa, este deve ser interpretado. Ora, os métodos de interpretação dos contratos são diferentes nos diversos sistemas jurídicos. Nos países pertencentes ao sistema anglo-saxão, bem como na França e nos países que seguem a tradição jurídica francesa, dentre os quais, de certa forma, se situa o Brasil, devese, em lugar de fixar o intérprete no sentido literal das palavras da convenção, perquirir-se qual foi a comum intenção das partes. Em oposição a este método subjetivo, segundo o qual se deve privilegiar a vontade interna dos contratantes sobre a expressão formal dessa vontade, o sistema germânico vincula-se à declaração de vontade das partes, interpretando-as, eventualmente, em função de dados objetivos. Essa divergência, talvez exagerada, dos métodos de interpretação fundada sobre a vontade real ou sobre a vontade expressa dos contratantes é acentuada pela diversidade das regras positivas de interpretação dos contratos. A extensão das obrigações, sendo, portanto, tributária da interpretação do contrato,torna necessário saber a que sistema o juiz da causa deve se referir.

Não se pode deixar sem menção aqui, apenas à guisa de introdução ao problema, as discussões havidas sobre que sistema jurídico à luz do qual deveriam ser interpretados no contrato: se o do local de sua conclusão, se de sua assinatura ou se do país onde se executariam as obrigações. Hoje, ao contrário, firma-se o princípio que impõe como competente a lei do contrato; de um lado, porque a interpretação do contrato é um problema de direito do qual depende o conteúdo do contrato. Além disso, pouco lógico seria não considerar que as partes, ao escolherem expressamente a lei aplicável ao contrato, referiramse ao conjunto do sistema legal eleito, tanto no que diz respeito à letra da lei como no que tange ao espírito da norma. Não obstante, torna-se necessário reconhecer que o princípio será sempre atenuado pela intervenção da lex fori, isso principalmente porque os juízes terão a tendência de se referirem a princípios de interpretação que utilizam habitualmente, ou seja, aqueles da lex fori. O problema se coloca diferentemente quando se trata de interpretar os termos do contrato. Ainda que estes possam ter influên- cia sobre o conteúdo das obrigações das partes, a interpretação dos termos utilizados é, com efeito, em princípio, uma questão de fato e concebe-se que a competência da lei do contrato não se imponha da mesma forma. As soluções quanto a este aspecto poderão ser diversas e só o prudente critério do juiz e o seu bom senso poderão orientar na interpretação dos termos do contrato. Ela será feita, algumas vezes, em função do sistema jurídico do país, da língua empregada no contrato; outras vezes será feita segundo a lei do lugar de execução, quando os termos ambíguos sejam relativos à execução do contrato. Outras vezes, ainda, será feita essa interpretação dos termos segundo a lei do lugar de assinatura do contrato, se a espécie assim o requerer. Os termos do contrato também poderão, em alguns casos, ser interpretados conforme as regras de interpretação elaboradas pela Câmara de Comércio Internacional, tais como, os inconterns, ou, ainda, conforme os usos e costumes do mundo dos negócios. Se a competência da lei do contrato, portanto, é limitada à interpretação stricto sensu do contrato, é razoável questionarmos se a determinação da natureza do contrato é igualmente uma questão de interpretação submetida à lei do contrato ou uma questão de qualificação submetida, em conseqüência, à lex fori.

Da qualificação dada ao contrato resulta a aplicação de regras diferentes, mas não a aplicação de uma lei diferente, isto porque não se trata, no caso, de uma verdadeira qualificação no sentido de direito internacional privado, ou seja, da qual dependerá, eventualmente, a vinculação legislativa do contrato, mas da interpretação do contrato submetido, em conseqüência, à lei do contrato. Se a lei do contrato parece ter competência, quando se trata de determinar as obrigações nascidas do contrato e seu conteúdo, deve ocorrer o mesmo quando essas são modificadas por força de circunstâncias posteriores à conclusão do contrato. O conteúdo das obrigações do contrato é, em princípio, determinado desde a assinatura do instrumento, mas ele pode vir a se modificar em função de circunstâncias posteriores, notadamente circunstâncias imprevisíveis, quando da conclusão do contrato. Poderão eles romper o equilíbrio das prestações das partes e tornar mais onerosa a execução das obrigações do devedor. Só a revisão do contrato pode estabelecer este equilíbrio.

Não são todas as legislações, porém, que cometem ao juiz o poder de modificar o contrato, ou mesmo de supri-lo, na ausência da vontade comum das partes. Pode-se, então, questionar se a revisão do contrato por imprevisão não deve estar referida ao poder do juiz da causa e, portanto, à lex fori. Na medida, porém, em que a revisão do contrato contém um atentado ao princípio da força obrigatória do contrato, e conduza a uma modificação do conteúdo das obrigações determinadas pela lei contratual, 
a competência da lei do contrato se impõe, salvo eventual interferência de ordem pública quando aquele conflite muito vivamente com as concepções do foro. O que se constata, então, é o grande domínio de intervenção da lei contratual para delimitar a extensão das obrigações criadas pelo contrato. A mesma situação deveria se encontrar quando se cuida de delimitar no tempo as obrigações do contrato. Veremos, porém, que não é sempre assim. A duração das obrigações depende do momento onde nascem as obrigações do contrato e do momento onde elas se extinguem: se pela execução do contrato ou por outros modos de extinção.

Paradoxalmente, é nesse domínio que a competência da lei do contrato é a menos geral, mas isto pode-se explicar na maioria das vezes, porque os modos de extinção das obrigações são variadas e não dependem exclusivamente do vínculo contratual em causa, como por exemplo, a compensação ou a novação. Em contrapartida, a prescrição das obrigações nascidas num contrato remetem-se sempre à lei do contrato.

Vale, portanto, ressaltar a importância, para tais fins e efeitos, de se precisar o momento no qual nascem as obrigações derivadas de um contrato internacional, particularmente quando este contrato é provido de um termo ou de uma condição.

Em princípio, as obrigações mascem coma assinatura do contrato, quando se firma o acordo de vontade dos contratantes, salvo quando houver convenção em contrário das partes, o que não encerra maiores problemas no campo do direito internacional.

O nascimento ou extinção das obrigações podem depender de um termo suspensivo ou extintivo, ou de uma condição suspensiva ou resolutiva, estipulados pelas partes, ou seja, de um acontecimento futuro, certo ou incerto, segundo se trate de termo ou condição. Os efeitos dessas modalidades de obrigações diferem sensivelmente segundo as legislações. Para se falar apenas em direito alienígena, por exemplo, na França, a obrigação é submetida a um termo suspensivo e existe desde logo a conclusão do contrato, ainda que ela não seja exigível antes do termo. Contrariamente, a obrigação submetida a uma condição suspensiva não existe senão enquanto e se a condição se cumpra. Mas o efeito principal reside na retroatividade da condição, quer ela seja suspensiva ou resolutiva. Este efeito não se verifica, por exemplo, no direito alemão que abandonou o princípio da retroatividade da condição.

Verifica-se, por isso, a fundamental importância de que uma lei precisa determinar as conseqüências das modalidades das obrigações. Esta lei não poderá ser outra senão a lei do contrato.
No que concerne à extinção das obrigações contratadas, por força da prescrição, é necessário que se diga que o assunto, durante muito tempo, provocou polêmica na doutrina e angústia e incerteza nos tribunais. A questão que se colocava era exatamente se a prescrição configurava um instituto de direito material ou um instituto de direito formal. Se a solução se inclinasse para a primeira hipótese, por conseqüência, uma vinculação à lei do contrato se impunha; caso se optasse pela segunda posição, a competência da lex fori seria legítima. A posição desta questão jurídica, no que dizia respeito ao direito interno, variava de país. Hoje, porém, a matéria é mais pacífica e se generaliza a idéia de que é mais conveniente descartar a qualificação procedimental da prescrição e observar-se a concepção de que ela se trata de instituição de direito material, referida, em conseqüência, à lei do contrato.

A execução do contrato, sendo a razão da existência dele, a lógica nos levaria a pensar que ela não pode estar submetida senão à lei aplicável a este contrato; porém, nessa matéria é que a competência da lei do contrato é menos prestigiada, tanto pela doutrina quanto pela jurisprudência.

A doutrina sempre teve alguma hesitação em admitir a competência da lei do contrato nessa matéria: ou o princípio era claramente afastado em proveito da lei do lugar de execução, ou a competência da lei do contrato era observada, mas com notáveis exceções relativas aos atos de execução e às modalidades de execução. Estas últimas exceções, notese, receberam grande consagração na jurisprudência anglo-saxônica. A noção de execução do contrato abrange, com efeito, elementos complexos; executar o contrato é executar as obrigações criadas pelo contrato.

Ora, para as executar e determinar a sua extinção é necessário cumprir atos de execução, ou seja, realizar certo trabalho, pagar um certo preço, entregar determinada mercadoria. Se o objeto da execução está diretamente ligado à determinação e à extensão das obrigações fixadas pela lei do contrato, os atos que levam ao seu atingimento apresentam um caráter distinto, porém a noção de execução engloba igualmente os problemas atinentes ao lugar da execução, aos momentos de execução ou as pessoas as quais incumbem ou as quais beneficiam a execução do contrato. O caráter material - e não mais somente conceitual da execução - conduz também a certas dúvidas sobre a competência da lei do contrato. Isto, por dois motivos diferentes: por uma razão de ordem prática, ou seja, pode ser mais fácil, mais cômodo para o devedor, cumprir os atos materiais da execução segundo as disposições em vigor no lugar da execução; uma outra razão mais imperiosa vai se opor a que sejam cumpridos atos 
contrários às prescrições imperativas do lugar de execução.

Assim, vemos que podemos, quando se trata de apreciar a validade do contrato, admitir a competência única da lei contratual, porque nos referimos à idéia abstrata de contrato, isto não é mais possível quando se trata da execução do contrato e da atividade material que ela comporta. Temos então que, se existem prescrições imperativas no lugar da execução, o devedor não as poderá evitar, quaisquer que sejam as disposições da lei do contrato. Parece-me que essas noções têm sido muito freqüentemente confundidas, isto porque é preferivel determinar no primeiro momento o domínio da lei do contrato em função da diferenciação dos elementos de execução, deixando-se para verificar a posteriori se as soluções baseadas no princípio devem receber exceções, levando-se em conta a natureza das disposições que podem ter uma influência sobre esses elementos.

Śem nos alongarmos em demasia, vamos examinar dois pontos para os quais a invocação da competência de outra lei que não aquela do contrato parece possível: Os atos de execução e as modalidades de execução. A doutrina tem distinguido o objeto da execução, ou seja, as obrigações nascidas do contrato, do ato que deve acarretar a extinção dessas obrigações e por consequeência a execução do contrato. Pode-se perfeitamente distinguir, por exem-

\section{Contratos estatais}

Ahmed Sadek El Kosheri, diretor da Faculdade de Direito da Universidade do Cairo, advogado do Mundo Árabe.

Contratos estatais têm sido objeto de muita discussão: uns advogam a internacionalização, enquanto outros pretendem a nacionalização. Certamente existem nuanças entre as duas posições, pois alguns são pela total internacionalização e outros apenas pela parcial. Eu sinceramente penso que o problema foi posto de forma errada em muitos escritos, tal como ficou recentemente provado por uma arbitragem a que o nosso presidente já se terá referido em algumas ocasiões. Posso relatar-lhes os fatos da demanda, porque eu julgo que o problema tenha sido solucionado, não devido aos meus esforços, mas aos de três distintos advogados, que foram os árbitros, tendo eu intervindo em defesa do governo do Kuwait contra a American Oil Company. O troisage, como dizem na França, produziu uma decisão unânime, em 24 de março de 1982 acerca de uma questão que eu plo, a obrigação de entregar uma mercadoria do ato de entrega; ou a obrigação de pagar o preço do próprio pagamento. A obrigação é dependente do contrato, mas sua execução exigia uma atividade material distinta. Verifica-se pois, e nesse sentido inclinamse a doutrina e a jurisprudência, que se pode legitimamente destacar os atos de execução da própria execução. Assim, ainda que se sobreleve uma presunção da submissão dos atos de execução à lei do contrato, tem-se admitido como igualmente possível a competência da lei do lugar de execução para regulá-los.

De maneira geral, pode-se dizer que a doutrina define a idéia de modalidade, ou forma de execução, de forma negativa. Assim, seria só mais uma modalidade de execução tudo que diga respeito à execução e não atinja a substância do contrato, ou seja, que não altere o montante da dívida. Estavam compreendidos na idéia de modalidade de execução, por exemplo, as prescrições contratuais relativas ao momento da execução, tais como, dias feriados, as disposições relativas às formas de remessa ou a entrega da coisa devida, as disposições que determinam a moeda de pagamento, a constituição em mora, etc. A doutrina atual é quase unânime no sentido de aceitar como adequada a aplicação da lei do lugar de execução às formas ou modalidade de execução do contrato.

\section{Ahmed Sadek El Kosheri}

julgo estabelecer a base, uma espécie de consenso entre as partes envolvidas nas transações em que o estado seja contratante. Resumidamente, o caso era um contrato de concessão de petróleo firmado em 1948 pelo xeque do Kuwait que nessa época não era ainda um país independente mas sim um protetorado britânico, com a companhia americana. Como contrato de concessão por sessenta anos, ele incluía as cláusulas normais, em cuja análise não vou entrar, entre elas a normalmente chamada cláusula de estabilização, o que significa que durante todo o prazo do contrato o xeque ou o seu sucessor não tinham qualquer direito a alterar ou mudar nenhuma das disposições do pacto sem o consentimento da outra parte, cláusula destinada, portanto, a estabilizar, a congelar as condições tais como eram em 1948; continha ainda a referência à arbitragem, devendo o ter- 